\title{
CREATING A SOCIALLY RESPONSIBLE AGRITOURISM OFFER. A MARKET REQUIREMENT OR A MANIFESTATION OF SERVICE PROVIDERS' SYSTEM OF VALUES?
}

\author{
MAGDALENA MAĆKOWIAK, ${ }^{1}$ LIBUŠE SVOBODOVÁ ${ }^{2}$
}

\footnotetext{
${ }^{1}$ University of Life Sciences in Poznań, POLAND

e-mail: mackowiak_magda@wp.pl

2 University of Hradec Kralove, CZECH REPUBLIC

e-mail: libuse.svobodova@uhk.cz
}

\section{RECEIVED: \\ ACCEPTED: \\ JEL \\ CLASSIFICATION}

KEYWORDS

ABSTRACT
28 April 2017

19 November 2017

$\mathrm{M} 310, \mathrm{Z} 390$

CSR in tourism, agritourism, market requirement

Making a profit is usually the main goal of an enterprise's activity, regardless of its size and the line of business it represents. However, due to the considerable complexity, unpredictability and changeability of the contemporary economic environment, the ways of achieving this aim are also very important. One of the conceptions considered by enterprises which include the interests of various groups into their activity is corporate social responsibility (CSR). Presumably, an enterprise which engages in activity in a conscious and planned way, gains the trust and support not only of its employees, but also clients, suppliers and local community, which may become a significant factor of its competitiveness and development.

A form of activity where corporate social responsibility can be applied is tourism.

The aim this article is to indicate the planes of implementing the assumptions of corporate social responsibility in tourism, as well as to find the answer to the question whether socially responsible activity, implemented by the owners of agritourist farms, may influence the perception of the offer attractiveness.

The question in the title concerns issues broader than the article. Due to the contributory nature of the study, the authors focused solely on presenting the results of the study on the demand side. 


\section{Introduction}

The fact that every aspect of human environment is influenced by various forms of economic activity is undeniable. This can be a positive or negative impact. It is only natural that the former is stressed more willingly and easier to accept. The latter often requires a stronger emphasis to make people aware of its existence. However, it is essential that problems are clearly stated, as it serves the purpose of building the sense of responsibility for finding solutions.

Creating the sense of social responsibility for business activity is a major issue in tourism as well. Its relations with the natural, economic and social environment are very strong (Cohen, 1978). Even though, in economic terms, the current and prospective leading trend is mass tourism, the "tourism of tomorrow" will certainly involve social responsibility (Goodwin, 2011; Leslie, 2012), whose assumptions should be taken into consideration with reference to both - the way of running the business and the tourists' behaviour.

The concept of responsible tourism is very close to the assumptions of rural tourism, but so far there has been no research on CSR implementation in this area (Sikora, 2012; Coles, Fenclova, Dinan, 2013).

The article is of contributory nature. Its aim is to indicate the planes of implementing the principles of corporate social responsibility in tourism, as well as to answer the question whether socially responsible activity of agritourist farms' owners may have an influence on the perception of offer attractiveness. Apart from the theoretical part, the article presents the results of surveys conducted among the actual and potential guests of agritourist farms.

\section{The ider of corporate sacial responsibility and its implementation in the tourism industry}

Social responsibility is considered to be one of the greatest challenges of the $21^{\text {st }}$ century and plays an increasingly important role in the functioning of many organizations. It is being discussed at length by researchers, both its theoretical (Friedman, 1970; Caroll, 1974 and 1991; Epstein, Roy, 2001) and empirical (Dahlsrud, 2008; Heslin, Ochoa, 2008) aspects. Corporate Social Responsibility may be understood as making and meeting economic, legal, ethical and discretionary commitments, imposed on a given organization by the parties engaged in its activity (Maignan, Ferrell, Hunt, 1999), or as considering the society's current expectations by the organization in its activity (Commission of the European Communities 2001).

A form of activity where the idea of corporate social responsibility can be applied is tourism. A growing number of tourism enterprises are incorporating this conception into their strategies, trying in this way to have a positive influence on the environment, the quality of life in the local communities and the well-being of their employees (Bohdanowicz, Zientara, 2009; Font, Walmsley, Cogotti, McCombes, Hausler, 2012; Kang, Lee, Huh, 2010).

As shown by the literature data, the main motivation causing enterprises to take interest in CSR is the reduction of costs, which gives them a competitive advantage (Knowles, Macmillan, Palmer, Grabowski, Hashimoto, 1999; Stabler, Goodal, 1997). This confirms Wheller's thesis (1991) that responsible tourism is a marketing trick rather than an ethical planning mechanism. Implementing CSR is also related, however, to the attempts to meet social expectations as regards responsibility (Bremner, 2009; Cheyne, Barnett, 2001; lan, 1996). Studies also point to altruistic motivations of implementing CSR in tourism (Ayuso, 2006; Tzschentke, Kirk, Lynch, 2004). Socially responsible activities in the tourism sector are varied, but they most frequently concern environment management, social dialogue and working relationships (Holcomb, Upchurch, Okumus, 2007; Karani, Day, 2011). 
H.Goodwin (2011) points out that responsible tourism is not a separate, isolated phenomenon, but it permeates all forms of human activity and evolves along with people's changing needs and attitudes. Preparing and providing every type of tourist product, both on and outside the market, involves specific activities as regards organization, task planning, using assets, and broadly understood cooperation, employment or finances. All these planes create an opportunity to show responsibility in the social, economic and environmental aspect.

This also concerns rural tourism and agritourism, whose greatest value shows in creating offers based on bottom-up initiatives, rooted in local communities developing on the basis of their resources. As a result, social capital is built, the inhabitants' economic situation improves, unemployment is reduced and the community becomes more integrated (Idziak, 2011).

\section{Research materials and method}

For the purpose of collecting primary data, a survey questionnaire was used, which consisted of two questions and a personal details section. Question 2 was a matrix containing 11 detailed questions, rated on the 5-grade Likert scale.

A diagnostic survey was conducted among some inhabitants of the Wielkopolskie province, in Februaryl March 2017. The researchers collected 72 correctly filled out questionnaires. With respect to the term "a large sample", used in statistics, that number was considered sufficient to run a contributory quantitative study. In general, a sample is considered to be relatively large if $n>50$ (Matykowski, 1992). According to J.T.Roscoe (1975), in most studies, an appropriate size of a sample should fall between over 30 and less than 500 .

The respondents were asked to rate the significance of some examples of socially responsible activities, included in the questionnaire as determinants of the choice of an agritourist offer.

\section{Results}

The change in the number of agritourist farms over the years has been the outcome of various factors, such as the tourist attractiveness of the area, the state policy at different levels of authority, the effectiveness and profitability of agricultural production, competition on the market, the seasonality of services, as well as the farmers' resourcefulness, motivations to engage in the activity, etc. (Konečný, 2014). The appearance of new suppliers on the agritourism market in subsequent years, as well as the large variety of goods makes it a highly competitive market.

The clear dominance of the economic elements over the social ones in the management of a small enterprise rarely motivates the entrepreneur to look for the pluses of competitive advantage in the social and intellectual sphere of activity. It turns out, however, that in the case of agritourist farms, signs of social responsibility in the legal, ethical or philanthropic aspect of activity may have an influence on the perception of the attractiveness of the offer by the actual or potential clients, who are among the most important stakeholders in the tourism business (Stawicka, 2016; Navrátilová, Lorinczová, Šišková, 2015).

Among the people participating in the survey, $41.7 \%$ were men and $58.5 \%$ were women. University education was indicated by $77.8 \%$ of the respondents, secondary education - by $19.4 \%$ and vocational education - by $2.8 \%$.

People aged $30-39(34.7 \%)$ and $40-49(27.8 \%)$ made up the highest proportion of respondents. A less numerous group consisted of people aged 50-59 (13.9\%) and over 60 (16.7\%), while the smallest one - of those aged below 30 (6.9\%). 
The majority of respondents came from cities inhabited by over 500,000 people (58.3\%). $45.8 \%$ described their financial situation as good, $43.1 \%$ - as average, only slightly over $8 \%$ - as very good and $2.8 \%$ - as bad.

Table 1 presents the percentage distribution of responses obtained for some examples of socially responsible activities, which could be offered by the owners of agritourist farms. The results point to its significance for the assessment of offer attractiveness.

The functioning of small enterprises largely depends on the style and effects of the owner's activity. Their knowledge, skills and experience determine the quality of company management. It is the individual system of values which are important to the owner of a small enterprise that determines his/her approach to implementing the principles of social responsibility.

Itseemsunderstandablethattherespondentsindicatedfirstofall thoseactivitiestheeffects of whichbenefited them directly. The majority believed that an important sign of social responsibility on the part of agritourism service providers, which has an influence on the choice of the offer, is honest communication with clients. It is particularly important in situation when information on agritourism facilities is very diverse and confusing (Havliček, Lohr, Benda, 2010). As many as $87.5 \%$ of the respondents claimed that a situation when the marketing information (e.g. an advertisement) agrees with the actual offer definitely has some influence on the perception of the attractiveness of a given farm. It was described as fairly significant by $8.3 \%$ of the respondents.

An equally high importance was ascribed to respecting the client's privacy (sensitive data, contact details, etc.). Such behaviour was regarded as a significant or fairly significant element of the offer attractiveness by $81.94 \%$ and $13.89 \%$ of respondents, respectively.

Table 1 Socially responsible actions and the perception of the agritourist offer attractiveness (\%)

\begin{tabular}{|c|c|c|c|c|c|}
\hline & Definitely yes & Rather yes & Hard to say & Rather no & Definitely no \\
\hline $\begin{array}{l}\text { Employment of staff on the } \\
\text { basis of a contract (job, } \\
\text { order, etc.) }\end{array}$ & 23.61 & 29.17 & 19.44 & 19.44 & 8.33 \\
\hline $\begin{array}{l}\text { Employment of staff from } \\
\text { the local society }\end{array}$ & 31.94 & 41.67 & 9.72 & 12.50 & 4.17 \\
\hline $\begin{array}{l}\text { Compliance with tax law in } \\
\text { terms of } \\
\text { conducted business }\end{array}$ & 31.94 & 26.39 & 15.28 & 19.44 & 6.94 \\
\hline $\begin{array}{l}\text { Raising own and } \\
\text { employees professional } \\
\text { qualifications }\end{array}$ & 31.94 & 27.78 & 25.00 & 13.89 & 1.39 \\
\hline $\begin{array}{l}\text { Compliance of marketing } \\
\text { information (eg advertising) } \\
\text { with the actual offer }\end{array}$ & 87.50 & 8.33 & 1.39 & 1.39 & 1.39 \\
\hline $\begin{array}{l}\text { Respecting customer } \\
\text { privacy (personal } \\
\text { information, contact, etc.) }\end{array}$ & 81.94 & 13.89 & 1.39 & 1.39 & 1.39 \\
\hline Charity and social activities & 16.67 & 31.94 & 34.72 & 11.11 & 5.56 \\
\hline $\begin{array}{l}\text { Use of environmentally } \\
\text { friendly products }\end{array}$ & 45.83 & 44.44 & 6.94 & 1.39 & 1.39 \\
\hline $\begin{array}{l}\text { Use of renewable energy } \\
\text { sources }\end{array}$ & 33.33 & 37.50 & 19.44 & 8.33 & 1.39 \\
\hline Waste segregation & 48.61 & 25.00 & 15.28 & 9.72 & 1.39 \\
\hline $\begin{array}{l}\text { Encourage the consumption } \\
\text { of organic products }\end{array}$ & 41.67 & 40.28 & 11.11 & 5.56 & 1.39 \\
\hline
\end{tabular}

Source: own research. 
In the respondents' opinion, other factors which have an influence on the attractiveness of the offer included solutions concerning environment protection and propagating pro-ecological behaviours, such as waste segregation or using environment-friendly products. Visible to the guests, they make assessment easier for them.

Respecting the tax law in business activity and considering various aspects related to the development of the local community are elements which the respondents believe to have a smaller impact on the attractiveness of the offer. A relatively large percentage of respondents did not see any relationship between the quality of service and the possibility of raising qualifications by the employees or the legal form of employment.

Charity activity in small enterprises is rather incidental and treated first of all as a marketing tool. Hence, it is probable that in this case, the respondents claimed more often than in the case of the other questions (34.72\%) that it was difficult for them to say whether this particular type of activity done by the farm owner would improve the perception of the offer attractiveness. It must be stressed, however, that almost half of the respondents considered this element to be highly or fairly significant.

\section{Conclusions}

Enterprises are obliged to observe moral and social norms and models of behaviour at each stage, as well as in every dimension of their activity, and not only after reaching the desired profit threshold. However, the choice between the two standpoints depends on the entrepreneur, and practically results from his/her knowledge and level of awareness.

Social responsibility in tourism may be manifested on multiple planes. This does not mean, however, that enterprises wishing to take decisions in compliance with this conception must show responsibility on all planes at the same time. In the case of small enterprises, which agritourist farms certainly are, the level of the farm owners' awareness of the role of social responsibility and their readiness to react properly to the emerging social problems, may result in gaining a competitive advantage related, for instance, to the perception of the offer attractiveness by potential clients.

\section{Referencens}

Ayuso, S. (2006). Adoption of voluntary environmental tools for sustainable tourism: Analysing the experience of Spanish hotels. Corporate Social Responsibility and Environmental Management, 13 (4), 207-220.

Bohdanowicz, P., Zientara, P. (2009). Hotel companies' contribution to improving the quality of life of local communities and the wellbeing of their employees. Tourism and Hospitality Research, 9 (2), 147-158.

Bremner, C. (2009). Sustainable tourism moves slowly in the right direction. Euromonitor International. London. Retrieved from: http:/l www.euromonitor.com/Sustainable_Tourism_Moves_Slowly_in_the_Right_Direction.

Caroll, A.B. (1991). The Pyramid of Corporate Social Responsibility: Toward the Moral Management of Organizational Stakeholders. Business Horizons, July-August, 39-48.

Carroll, A.B. (1974). Corporate Social Responsibility: Its Managerial Impact and Implications. Journal of Business Research, 2 (1), 75-88.

Cheyne, J., Barnett, S. (2001). The greening of accommodation: Stakeholder perspectives of environmental programmes in New Zealand hotels and luxury lodges. Journal of Corporate Citizenship Spring.

Cohen, E. (1978). The impact of tourism on the physical environment. Annals of Tourism Research, 5 (2), 215-237.

Coles, T., Fenclova, E., Dinan, C. (2013). Tourism and corporate social responsibility: A critical review and research agenda. Tourism Management Perspectives 6, 122-141.

Commission of the European Communities (2001). Green Paper, Promoting Framework for Corporate Social Responsibility. Brussels.

Dahlsrud, A. (2008). How corporate social responsibility is defined: An analysis of 37 definitions. Corporate Social Responsibility and Environmental Management, 15, 1-13.

Epstein, M.J., Roy, M.J. (2001). Sustainability in action: Identifying and measuring the key performance drivers. Long Range Planning, $34(5), 585-604$. 
Font, X., Walmsley, A., Cogotti, S., McCombes, L., Häusler, N. (2012). Corporate social responsibility: The disclosure-performance gap. Tourism Management, 33, 1544-1553.

Friedman, M. (1970). The social responsibility of business is to increase its profits. The New York Times Magazine, 13/09/1970, 32-33, 122-126.

Goodwin, H. (2011). Taking Responsibility for Tourism. Oxford: Goodfellow Publishers Limited.

Havliček, Z., Lohr, V. \& Benda, P. (2010). ICT Support for Agritourism. In: 19th International Scientific Conference on Agrarian Perspectives, 327-334.

Heslin, P.A., Ochoa, J.D. (2008). Understanding and developing strategic corporate responsibility. Organizational Dynamics, 37 (2), 125-144.

Holcomb, J.L., Upchurch, R.S., Okumus, F. (2007). Corporate social responsibility: What are top hotel companies reporting? International Journal of Contemporary Hospitality Management, 19 (6), 461-475. Retrieved from: http://responsibletourismpartnership.org/ cape-town-declaration-on-responsible-tourism (16.3.2017).

Ian, R. (1996). From shareholders to stakeholders: Critical issues for tourism marketers. Tourism Management, 17 (7), 533-540.

Idziak, W. (2011). Turystyka społeczna - inspiracje dla turystyki wiejskiej. Folia Pomer. Univ. Technol. Stetin. Oeconomica, 288 (64), 9-18.

Kang, K.H., Lee, S., Huh, C. (2010). Impacts of positive and negative corporate social responsibility activities on company performance in the hospitality industry. International Journal of Hospitality Management, 29 (1), 72-82.

Karani, A.P., Day, J.G. (2011). Corporate social responsibility and employee recruiting in the tourism industry. Retrieved from: http:/l scholarworks.umass.edu/cgi/viewcontent.cgi?article=1248\&_context=gradconf_hospitality (17.3.2017).

Knowles, T., Macmillan, S., Palmer, J., Grabowski, P., Hashimoto, A. (1999). The development of environmental initiatives in tourism: Responses from the London hotel sector. International Journal Of Tourism Research, 1 (4), 255-265.

Konečný, O. (2014). Geographical Perspectives on Agritourism in the Czech Republic. Moriavian Geographical Reports, 22 (1), 15-23.

Leslie, D. (2012). Responsible Tourism. Concepts, Theory and Practice. CABI, Wallingford.

Maignan, I., Ferrell, O.C., Hult, G.T.M. (1999). Corporate Citizenship: Cultural Antecedents and Business Benefits. Journal of the Academy of Marketing Science, 27 (Fall), 455-469.

Matykowski, Z. (1992). Zbieranie i tworzenie informacji w badaniach społeczno-geograficznych: problemy i trudności. In: Z. Chojnicki, T. Czyż (eds.), Współczesne problemy geografii społeczno-ekonomicznej Polski (pp. 149-161). Seria Geografia 55. Poznań: Uniwersytet im. Adama Mickiewicza w Poznaniu.

Navrátilová, M., Lorinczová, E., Šišková, J. (2015). Assessment of Young People's Expectations of Agritourism in the Czech Republic. In: 24th International Scientific Conference on Agrarian Perspectives - Global Agribusiness and the Rural Economy, 316-323.

Roscoe, J.T. (1975). Fundamental Research Statistics for the Behavioural Sciences, 2nd edition. New York: Holt Rinehart \& Winston.

Sikora, J. (2012). Idea społecznej odpowiedzialności biznesu w agroturystyce [The idea of corporate social responsibility in agritourism]. In: J. Wołoszyn (ed.), Społeczna odpowiedzialność biznesu w obszarze przedsiębiorczości (pp. 25-36). Warszawa: Wydawnictwo SGGW.

Sokołowska, A. (2009). Społeczna odpowiedzialność małego przedsiębiorstwa - przejawy i dylematy [Corporate social responsibility symptoms and dilemmas]. E-mentor, 5 (32). Retrieved from: http://www.e-mentor.edu.pl/artykul/index/numer/32/id/691 (19.03.2017).

Stabler, M.J., Goodal, B. (1997). Environmental awareness action and performance in the Guernsey hospitality sector. Tourism Management, 18 (1), 19-33.

Stawicka, E. (2016). Aspekt społecznej odpowiedzialności w turystyce [An aspect of social responsibility in tourism]. Turystyka i Rozwój Regionalny, 6, 99-111.

Tzschentke, N., Kirk, D., Lynch, P.A. (2004). Reasons for going green in serviced accommodation establishments. International Journal of Contemporary Hospitality Management, 16 (2), 116-124.

Wheeller, B. (1991). Tourism's troubled times: Responsible tourism is not the answer. Tourism Management, 12 (2), 91-96.

Zeliaś, A. (2000). Metody statystyczne [Statistical methods]. Warszawa, PWE.

Cite this article aS: Maćkowiak, M., Svobodová, L. (2017). Creating a socially responsible agritourism offer. A market requirement or a manifestation of service providers' system of values? European Journal of Service Management, 4 (24), 39-44. DOI: 1.18276/ ejsm.2017.24-06. 